\title{
ПРОГНОЗУВАННЯ ПАТОЛОГІЧНИХ ЗМІН НА ЕЛЕКТРОЕНЦЕФАЛОГРАМІ МЕТОДАМИ НЕЛІНІЙНОї ДИНАМІКИ
}

\author{
Юр'єва К.О., ст. викладач \\ kat.yurieva@gmail.com \\ м. Київ, Україна \\ Білошицька О.К., ст. викладач \\ ksenia_bil@ukr.net \\ Кафедра біомедичної інженерії \\ Національний технічний університет України \\ «Київський політехнічний інститут імені Ігоря Сікорського»
}

\begin{abstract}
Реферат - Створено програмний комплекс для дослідження та аналізу електроенцефалографічних сигналів у середовищі Matlab з використання методів нелінійної динаміки. Сформовано електронну базу ЕЕГ-даних пацієнтів з різними патологічними станами та з нормальною графікою ЕЕГ. Обтрунтувано застосування методів нелінійної динаміки при прогнозуванні епілептичних нападів. Показана залежність між значеннями показників та станом мозку.
\end{abstract}

Ключові слова - електроенщефалографія, нелінійна динаміка, показник Херста, R/S аналіз, фазовий портрет, епілепсія, Маtlab.

\section{I. ВСТУП}

Сучасна електроенцефалографія (ЕЕГ) дозволяє неінвазивно і безпечно, без обмежень y часі i незалежно від стану людини досліджувати стан центральної нервової системи. Існує багато традиційних способів аналізу електроенцефалограм, зокрема, візуальна діагностика, спектральний аналіз, кореляційний аналіз, які $€$ складовими діагностичного інструментарію.

За допомогою вищезгаданих методів можна описати роботу головного мозку в цілому, не розглядаючи процесів, що породжуються нейронами та їх популяціями. Подібні теоретичні моделі, що реалізують системний підхід до діяльності мозку та описують фізіологічні процеси, описані у дослідженнях $[1,2]$. Але отримані результати електроенцефалографічного дослідження традиційним методом важко співставити 3 існуючими моделями.

Ще одним напрямком $є$ дослідження ЕЕГ з позицій теорії динамічного хаосу. Згідно цієї теорії ЕЕГ можна представити як хаотичний процес. За допомогою кореляційної розмірності відновленого аттрактору можна характеризувати на скільки складна система та процес, який вона відображає. А за допомогою статистичних та математичних методів істотно зростає інформативність ЕЕГ [11].

На даний час $\epsilon$ досить актуальною задача побудови алгоритмів, що дозволяють повністю автоматизувати процедуру аналізу ЕЕГ методами нелінійної динаміки, що застосовуються на сучасному етапі для цієї мети. Отже, створення програмного комплексу для прогнозування патологічних змін на ЕЕГ за допомогою методів нелінійної динаміки $€$ актуальною задачею.

\section{II. МЕТА ДОСЛІДЖЕННЯ}

Метою роботи $є$ обгрунтування достовірності застосування методів нелінійної динаміки при прогнозуванні епілептичних нападів у хворих.

Клініцисти-неврологи та нейрохірурги, насамперед, думають термінами структури та функціями головного мозку, а не термінами абстрактних ритмів: альфа-, бета- та інших. А лікар 3 функціональної діагностики саме такими термінами i користується. Отже, потрібно знайти консенсус між трактуванням ЕЕГ, що використовуються неврологом при лікуванні хворого, нейрохірургом при оперативному втручанні, та вченим, що вивчає дану область. Тому гостро відчувається потреба в нових методах дослідження, які 
зможуть дати суттєвий прогрес у вивченні природи електричної активності головного мозку та їі зв’язку зі структурою та функцією.

\section{II. МЕТОДИ РЕССТРАЦІЇ ТА ОБРОБКИ СИГНАЛІВ ЕЕГ}

У практиці клінічній та науковій електроенцефалографії стандартом $\epsilon$ схема «10-20\%», яку було введено канадським нейрофізіологом Генрі Джаспером (рис. 1).
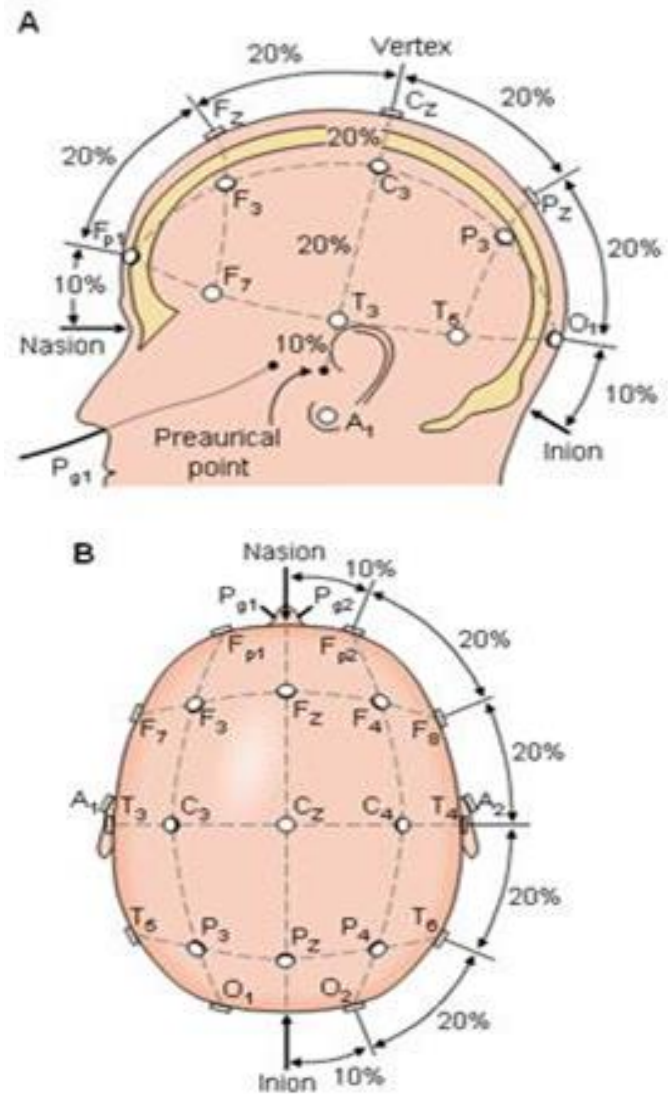

Рис. 1. Схема розташування електродів за міжнародною системою 10-20\%

Для отримання точної інформації під час електроенцефалографічного дослідження дотримуються певні загальні правила. Оскільки, ЕЕГ відображає рівень функціональної активності мозку i дуже чутлива до змін рівня уваги, емоційного стану, впливу зовнішніх факторів, пацієнт під час дослідження повинен знаходитися в світло- i звукоізольованому приміщенні. Найкращим $\epsilon$ положення обстежуваного напівлежачи в зручному кріслі, м'язи розслаблені. Голова спочиває на спеціальному підголівнику. Необхідність розслаблення, крім забезпечення максимального спокою обстежуваного, визначається тим, що напруга м'язів, особливо голови i шиї, супроводжується появою артефактів електроміографії в запису. Очі пацієнта під час дослідження повинні бути закриті, так як при цьому спостерігається найбільша вираженість нормального $\alpha$-ритму на ЕЕГ, а також деяких патологічних феноменів у хворих.

Для виявлення реагування мозку на зовнішні впливи, зокрема при дослідженні ступеня збереження свідомості хворого, застосовують поодинокі стимули у вигляді короткого спалаху світла, звукового клацання або тону [3]. Для нанесення світлових i звукових подразнень використовуються фотоi фоностимулятори. Для фотостимуляції використовуються короткі (близько 150 мкс) спалахи світла, близькі по спектру до білого, досить високої інтенсивності $(0,1$ - 0,6 Дж). Крім одиночних спалахів світла, фотостимулятори дозволяють відтворювати однакові спалахи бажаної частоти i тривалості, які застосовують для дослідження реакції засвоєння ритму - здатності ЕЕГ коливань відтворювати ритм зовнішніх подразнень.

Оскільки тривалість нападів може бути різною - від однієї до кількох секунд, вони можуть бути виражені у вигляді «фонової» пароксизмальної активності в одній, декількох або всіх областях мозку одного або обох його півкуль. На тлі біопотенціалів, представлених більш-менш регулярними, краще або гірше ритмізованими альфа-, бета- i повільними коливаннями, пароксизми найрізноманітніших конфігурацій раптово з'являються і так само раптово зникають. Вони можуть складатися 3 високоамплітудних (до 100-200 Мкв і більше) альфа-, тета- і дельта-хвиль гладкої або загостреної форми; 3 особливого роду однофазних потенціалів - піків і гострих хвиль; 3 нечітких ЕЕГ комплексів, що складаються 3 хвиль різного роду; 3 чітких комплексів «пік-Хвиля».

Поява на ЕЕГ спалахів і пароксизмів багато років традиційно вважалась специфічною для епілептичної хвороби. Однак до теперішнього часу в літературі все частіше зустрічаються дані, які заперечують таку специфічність ЕЕГ [4 - 6]. Серед пароксизмальних форм біопотенціалів комплекси «пік-хвиля» і «хвиля-пік», мають більш безпосереднє відношення до механізмів 
розвитку епілептичних станів. Проте, багато пароксизмальних станів можуть бути помилково прийняті за епілептичний припадок. Для таких специфічних станів доводиться проводити диференційний діагноз ЕЕГ, в тому числі з використанням методів нелінійної динаміки [11].

\section{IV. ЗАСТОСУВАННЯ МАТЕМАТИЧНОГО АНАЛІЗУ ПРИ ДОСЛІДЖЕННІ ЕГГ}

Найбільш розповсюдженими методами, які використовуються для обробки даних ЕЕГ, $\epsilon$ швидке перетворення Фур'є, вейвлетперетворення та спектральний аналіз. Оцінка частотних складових ЕЕГ використовується для локальної діагностики, оскільки саме ця характеристика ЕЕГ є одним із головних критеріїв при візуальному пошуку локальних уражень мозку.

В основі математичного аналізу ЕЕГ покладено перетворення початкових даних методом швидкого перетворення Фур'є. Початкова електроенцефалограма після ii1 перетворення у дискретну форму розбивається на послідовні сегменти, кожен 3 яких використовується для побудови відповідної кількості періодичних сигналів, які потім піддають гармонічному аналізу. Вихідні форми представляються у вигляді числових значень, графіків, графічних карт, стиснутих спектральних областей, ЕЕГ-томограм та ін.

Одним 3 перспективних способів аналізу, очистки та стиснення різних видів сигналів ЕЕГ $\epsilon$ вейвлет-перетворення. Пропонований метод розрахунку кореляцій різних каналів ЕЕГ базується на вираховуванні спектральних інтегралів за допомогою вейвлет-перетворення сигналів. Даний підхід дозволяє виконати просторово-часовий аналіз наростання та згасання спалахів активності, що виникають в різних структурах кори головного мозку [7].

Досліджувалися як дорослі особи різного віку та статі, так і діти. Всього було знято понад 50 ЕЕГ, але для аналізу було виділено лише 20 досліджень. Візуальний аналіз ЕЕГ здійснювався за допомогою програми ExpertNet (рис. 2). У програмі застосовується поділ екрану: на одній половині можна контролювати реєстрацію ЕЕГ і переглядати iii графіку, на другій - відеомоніторинг запису.

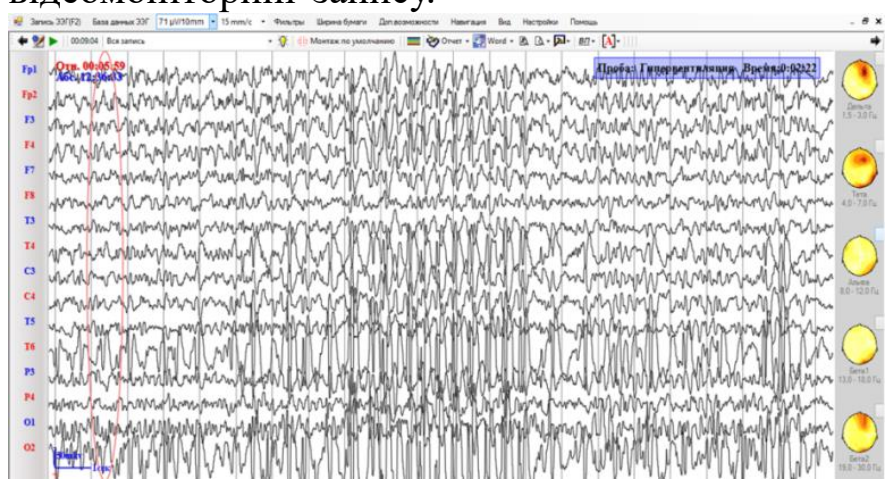

Рис. 2. Візуалізація ЕЕГ в програмі ExpertNet

Досліджувані пацієнти протягом 3 тижнів перебували в умовах, рекомендованих при проведенні ЕЕГ-досліджень. Запис ЕЕГ проводився за міжнародною схемою відведень «10-20» 3 використанням 16-канального телеметричного електроенцефалографа Expert компанії Tredex 3 відеомоніторингом 3 верхнім граничним фільтром 30 Гц, постійної часу 0,1 с і $з$ частотою дискретизації 400 Гц.

Функціональні проби проводилися в наступній послідовності: фонова (1 хвилина), очі закриті (30 секунд), очі відкриті (30 секунд), фотостимуляція на різних частотах 6 Гц, 8 Гц, 9 Гц, 10 Гц, 14 Гц, 16 Гц, 18 Гц, 20 Гц (кожна по 15 секунд, сумарно 2 хвилини), гіпервентиляція (3 хвилини), фонова (1 хвилина), очі відкриті (30 секунд), очі закриті (30 секунд). В цілому весь запис тривав 9 хвилин.

Отримана база даних ЕЕГ була розділена на 3 групи: вогнищеві ураження (4 особи), системні ураження (8 осіб) і норма (8 осіб) [11]. До групи вогнищевих уражень було віднесено пацієнтів з діагнозами з кодуванням за МКХ-10 G40 Епілепсія, G404 Інші види генералізованої епілепсії та епілептичних синдромів та С71 Злоякісне новоутворення головного мозку. До групи системних уражень віднесено наступні діагнози за МКХ-10: I67 Інші цереброваскулярні хвороби, I679 Цереброваскулярна хвороба, неуточнена та I67A Інші цереброваскулярні хвороби 3 гіпертонічною хворобою [8]. Для норми були відібрані пацієнти без патологій з кодуванням за MKX-10 Z00 Загальний огляд та обстеження осіб при відсутності скарг або встановленні діагнозу [9].

Математичний аналіз при дослідженні ЕЕГ здійснювався за допомогою програмного 
середовища Matlab[10]. Розроблене програмне забезпечення реалізує R/S-аналіз, який вираховує показник Херста та будує фазовий портрет з біфуркаційною діаграмою.

Реалізований у Matlab R/S-аналіз має натупний алгоритм [11]:

1. Визначається вихідний ряд $\mathrm{Xn}$ часової послідовності значень певного відведення ЕЕГ:

$$
\mathrm{X}_{\mathrm{n}}=\mathrm{x}_{1}, \mathrm{x}_{2}, \ldots \mathrm{x}_{\mathrm{n}} \text {. }
$$

2. Для кожного значення $\mathrm{n}$ знаходиться середнє арифметичне значення елементів послідовності:

$$
\overline{\mathrm{x}_{\mathrm{n}}}=\left(\mathrm{x}_{\mathrm{k}}\right)_{\mathrm{k}=1}^{\mathrm{n}}
$$

Оскільки послідовність відведення ЕЕГ містить різну кількість позитивних i негативних значень, необхідно нормувати Xn так, щоб отримати ряд, середнє значення якого рівне 0. Для цього необхідно вирахувати 3 кожного значення, середнє по виборці.

3. Обчислюється середньоквадратичне відхилення ЕЕГ відведення за 1 секунду запису:

$$
S_{n}=\sqrt{\frac{1}{n} \sum_{i=1}^{n}\left(x_{i}-\overline{x_{n}}\right)^{2}} .
$$

4. Визначається розмах накопичених сум за час реєстрації ЕЕГ:

$$
\begin{gathered}
\mathrm{R}_{\mathrm{n}}=\max _{\mathrm{k}=1, \ldots, \mathrm{n}}\left(\sum_{\mathrm{i}=1}^{\mathrm{k}}\left(\mathrm{x}_{\mathrm{i}}-\overline{\mathrm{x}_{\mathrm{n}}}\right)\right)- \\
\min _{\mathrm{k}=1, \ldots, \mathrm{n}}\left(\sum_{\mathrm{i}=1}^{\mathrm{k}}\left(\mathrm{x}_{\mathrm{i}}-\overline{\mathrm{x}_{\mathrm{n}}}\right)\right) .
\end{gathered}
$$

5. Вираховується нормований розмах накопичених сум:

$$
(\mathrm{RS})_{\mathrm{n}}=\frac{\mathrm{R}_{\mathrm{n}}}{\mathrm{S}_{\mathrm{n}}} \text {. }
$$

6. Обраховується показник Херста, який має зв'язок з нормованим розмахом сум, за формулою:

$$
\mathrm{E}\left[\frac{\mathrm{R}_{\mathrm{n}}}{\mathrm{S}_{\mathrm{n}}}\right]=\mathrm{Cn}^{\mathrm{H}} \text {, }
$$

де $\mathrm{E}$ - математичне очікування, $\mathrm{C}$ константа, $\mathrm{H}$ - показник Херста.
7. Знайшовши значення $\mathrm{R} / \mathrm{S}$ для кожного значення вибірки, 3 цих значень форується послідовність точок на площині:

$$
\left(x_{n}, y_{n}\right) \equiv\left(\ln n, \ln (R S)_{n}\right)_{n=1}^{N} \text {. }
$$

8. Застосувавши метод найменших квадратів знаходимо коефіцієнт Херста:

$$
\mathrm{H}=\frac{\mathrm{Ng}_{1}-\mathrm{c}_{2} \mathrm{~g}_{2}}{\mathrm{Nc}_{1}-\mathrm{c}_{2}^{2}},
$$

де $\mathrm{c}_{1}, \mathrm{c}_{2}, \mathrm{~g}_{1}, \mathrm{~g}_{2}$ - допоміжні константи методу найменших квадратів (МНК):

$$
\begin{aligned}
& \mathrm{c}_{1}=\sum_{\mathrm{i}=1}^{\mathrm{N}} \mathrm{x}^{2}, \mathrm{c}_{2}=\sum_{\mathrm{i}=1}^{\mathrm{N}} \mathrm{x} ; \mathrm{g}_{1}= \\
& \sum_{\mathrm{i}=1}^{\mathrm{N}} \mathrm{xy}, \mathrm{g}_{2}=\sum_{\mathrm{i}=1}^{\mathrm{N}} \mathrm{y} .
\end{aligned}
$$

9. Для побудови біфуркаційної діаграми формулюється логістичне відображення:

$$
x_{n+1}=\operatorname{rx}_{n}\left(1-x_{n}\right),
$$

де $\mathrm{x}_{\mathrm{n}}-$ приймає значення від 0 до 1 i відображає значення відведення в n-ому відліку запису ЕЕГ, r - позитивний параметр, що характеризує ріст цього значення.

Таким чином, математичний аналіз при дослідженні ЕЕГ у Matlab дає змогу сформувати вектор значень показника Херста для кожного відведення ЕЕГ.

\section{V. РЕЗУЛЬТАТИ АНАЛІЗУ ЕЕГ}

Запропонований алгоритм, що реалізовано в програмному середовищі Matlab дає змогу провести дослідження дієвості нелінійних показників за зібраною базою даних ЕЕГ пацієнтів.

На рисунку 3 зображено результат обробки одного відведення ЕЕГ пацієнта А, створеним програмним продуктом, під час спокою [11]. На екран виведена ділянка, що містить 1900 відліків (що відповідає близько 10 секундам запису ЕЕГ). За рекомендацією лікарів відділення, де було зібрано дослідну базу даних, був обраний інтервал електроенцефалограми, який містить проведення функціональної проби гіпервентиляція. 
Перший графік відображає значення відведення F7, другий - результат R/S-аналізу, третій - значення показника Херста.

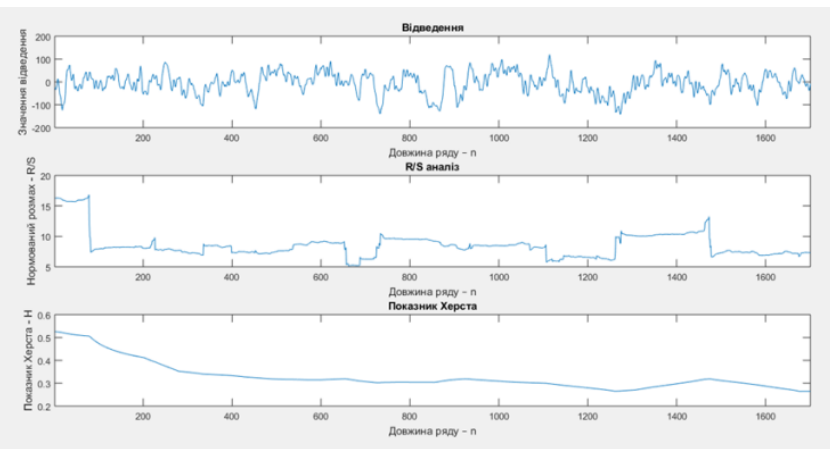

Рис. 3. Результат R/S-аналізу 10-секундного запису одного відведення пацієнта А під час спокою

Як бачимо 3 рисунку 3 , R/S-аналіз чутливий до змін значень відведення. Він виокремлює візуально ділянки різних «стрибків» активностей, а показник Херста не має різких змін значень, адже епілептична активність на даному проміжку відсутня. Значення коливається в околі $\mathrm{H} \sim 0.3$.

На рисунку 4 зображено результат обробки ЕЕГ пацієнта А, вже під час епілептичної активності. На екран виведена ділянка, що містить 1900 відліків, що відповідає близько 10 секундам запису ЕЕГ. За рекомендацією лікарів відділення, був також обраний інтервал, який містить проведення функціональної проби - гіпервентиляція.

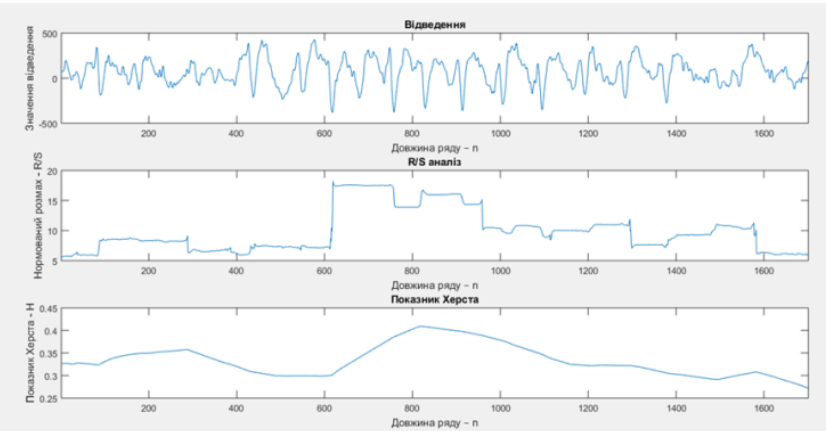

Рис. 4. Результат R/S-аналізу 10-секундного запису одного відведення пацієнта А під час нападу

Як бачимо з графіків на рисунку 4 у вікні, де зображене відведення, чітко видно епілептичну активність головного мозку. Відповідно R/S-аналіз має підвищення значень під час патології. Значення показника Херста починає зростати при настанні епілептичної активності та спадати, що свідчить про майбутне припинення нападу. Значення показника Херста під час нападу знаходиться в межах 0.35-0.44, а потім знову повертається до значень близьких $\mathrm{H} \sim 0.3$.

У результаті оцінки показника Херста та значень R/S-аналізу, встановлені такі результати для пацієнтів групи «вогнищеві ураження» при патології (таблиця 1):

Таблиця 1.

Показник Херста групи «вогнищеві ураження»

\begin{tabular}{|l|c|}
\hline \multicolumn{1}{|c|}{ Функціональна проба } & Показник Херста (Н) \\
\hline Очі відкриті & $0.412 \ldots 0.445$ \\
\hline Очі закриті & $0.344 \ldots 0.434$ \\
\hline Гіпервентиляція & $0.356 \ldots 0.428$ \\
\hline Фотостимуляція & $0.358 \ldots 0.432$ \\
\hline
\end{tabular}

Результати візуальної реконструкції для пацієнта А під час спокою та патології, зображено на рисунках 5 і 6 .

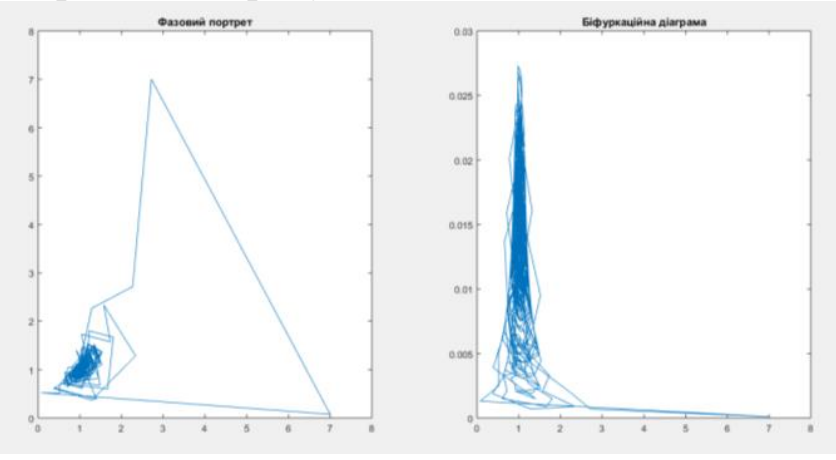

Рис. 5. Фазовий портрет (ліворуч) та біфуркаційна діаграма (праворуч) пацієнта А у стані спокою

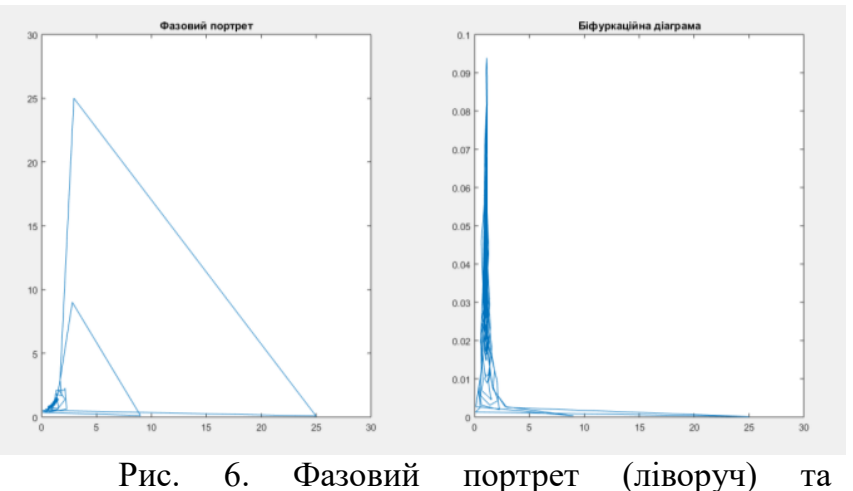

біфуркаційна діаграма (праворуч) пацієнта А у стані епілептичної активності

Аналізуючи біфуркаційну діаграму, за показником $\mathrm{r}$, що розташований по осі абсцис, бачимо, що значення зосереджене в межах від 0 до 2. Це свідчить про те, що чисельність популяції збуджених нейронів швидко вийде на стаціонарне значення, незалежно від початкових умов. При цьому найбільш високі значення показник Херста приймає в тих 
областях мозку, де більш виражені системні порушення. Також високі значення спостерігались за зорової активності, фотостимуляції, гіпервентиляції, а мінімальні - при закритих очах.

Отже, використання методів нелінійної динаміки $є$ сильним поштовхом до прогнозування патологічних активностей. Поліпшення результатів можливо досягнути шляхом досконалого усунення артефактів на ЕЕГ та встановлення чіткого розуміння, який сигнал ЕЕГ є нормою, а на якому реєструється патологічна активність або системні зміни.

\section{ПЕРЕЛІК ПОСИЛАНЬ}

[1] Зенков Л.Р. Функциональная диагностика нервных болезней / Л.Р. Зенков, М. А. Ронкин. - Москва: МЕДпрессинформ, 2013. - 488 с.

[2] Гнездицкий В.В. Обратная задача ЭЭГ и клиническая электроэнцефалография / В.В. Гнездицкий. - Москва: МЕДпресс-информ, 2004. - 624 с.
[3] Хакен Г. Принципы работы головного мозга / Г. Хакен. Москва: ПЕР СЭ, 2001. - 352 с.

[4] Жирмунская Е. А. Клиническая электроэнцефалография / Е. А. Жирмунская., 1998. - 156 с.

[5] Поворинский А. Г. Значение ЭЭГ-показателей для оценки функционального состояния головного мозга / А. Г. Поворинский. - Москва: Медицина, 1998. - 51 с.

[6] Сараджишвили П. М. Эпилепсия / П. М. Сараджишвили, Т. Ш. Геладзе. - Москва: Медицина, 1998.

[7] Калуш Ю.А. Показатель Хёрста и его скрытые свойства / Ю. А. Калуш, В.М. Логинов. // Сиб. журн. индустр. матем. 2002. - №4. - C. 29-37.

[8] Ситникова Е.Ю. Анализ электрической активности головного мозга при абсанс-эпилепсии: прикладные аспекты нелинейной динамики / Е.Ю. Ситникова, А.А. Короновский, А.Е. Храмов // Известия вузов «ПНД». Нелинейная динамика и нейронаука. 2011. Т.19, №6. С.173-182.

[9] Меклер А. А. Программный комплекс для анализа электроэнцефалограмм методами теории динамического хаоса: 05.13.18 / Меклер А. А., 2006. - 168 с.

[10] Лазарєв Ю.Ф. МАТLAВ і моделювання динамічних систем / Ю.Ф. Лазарєв // Навчальний посібник / Ю.Ф. Лазарєв., 2009.

[11] Білошицька О.К. Нелінійна динаміка як інструмент прогнозування патологічних змін на електроенцефалограмі // Вісник НТУ “ХПІ”. - 2016. - №50 (1222). - С. 79 - 83. 


\section{ПРОГНОЗИРОВАНИЕ ПАТОЛОГИЧЕСКИХ ИЗМЕНЕНИЙ НА ЭЛЕКТРОЭНЦЕФАЛОГРАММЕ МЕТОДАМИ НЕЛИНЕЙНОЙ ДИНАМИКИ}

Юрьва К. $\boldsymbol{A}$. , ст. преподаватель kat.yurieva@gmail.com

м. Київ, Україна

Белошицкая $\boldsymbol{A . K . , ~ с т . ~ п р е п о д а в а т е л ь ~}$

ksenia_bil@ukr.net

Кафедра биомедицинской инженерии

Национальный технический университет Украины «Киевский политехнический институт имени Игоря Сикорского»

Реферат - Создан программный комплекс для исследования и анализа электроэнцефалографических сигналов в среде Маtlab c использованием методов нелинейной динамики. Сформирована электронная база ЭЭГ-данных пациентов с различными патологическими состояниями и с нормальной графикой ЭЭГ. Обосновано применение методов нелинейной динамики при прогнозировании эпилептических припадков. Показана зависимость между значениями показателей и состоянием мозга.

Ключовые слова - электроэнцефалография, нелинейная динамика, показатель Херста, R/S анализ, фазовый портрет, эпилепсия, Matlab.

UDC 616.1-616.7

\section{FORECASTING OF PATHOLOGICAL CHANGES ON THE ELECTROENCEPHALOGRAM BY METHODS OF NONLINEAR DYNAMICS}

Yurjeva K.A., Senior Lecturer kat.yurieva@gmail.com metro Kiev, Ukraine

Biloshytska O.K., Ph.D., Senior Lecturer ksenia_bil@ukr.net

Department of Biomedical Engineering National Technical University of Ukraine "Igor Sikorsky Kyiv Polytechnic Institute"

Kyiv, Ukraine

Abstract - The software package has been created for the study and analysis of electroencephalographic signals in Matlab using nonlinear dynamics methods. An electronic database of EEG data of patients with various pathological conditions and with normal EEG graphics has been formed. The use of nonlinear dynamics methods in predicting epileptic seizures is justified. The relationship between the values of indicators and the state of the brain is shown. 